\title{
Cloning and Expression of the Organophosphate Pesticide-Degrading $\alpha-\beta$ Hydrolase Gene in Plasmid pMK-07 to Confer Cross-Resistance to Antibiotics
}

\author{
Kirubakaran Rangasamy, ${ }^{1}$ Murugan Athiappan $\left(\mathbb{D},{ }^{1}\right.$ Natarajan Devarajan, ${ }^{2}$ \\ Javid A. Parray, ${ }^{3}$ Nowsheen Shameem, ${ }^{4}$ K. N. Aruljothi (iD, ${ }^{5}$ Abeer Hashem, ${ }^{6,7}$ \\ Abdulaziz A. Alqarawi, ${ }^{8}$ and Elsayed Fathi Abd_Allah (iD) 8 \\ ${ }^{1}$ Department of Microbiology, Periyar University, Salem, Tamil Nadu, India \\ ${ }^{2}$ Department of Biotechnology, Periyar University, Salem, Tamil Nadu, India \\ ${ }^{3}$ Department of Environmental Science, Government SAM Degree College Budgam, Jammu \& Kashmir 191111, India \\ ${ }^{4}$ Department of Environmental Science, Cluster University Srinagar, Jammu \& Kashmir 190001, India \\ ${ }^{5}$ Department of Genetic Engineering, SRM University, Chennai, Tamil Nadu, India \\ ${ }^{6}$ Botany and Microbiology Department, College of Science, King Saud University, P.O. Box 2460, Riyadh 11451, Saudi Arabia \\ ${ }^{7}$ Mycology and Plant Disease Survey Department, Plant Pathology Research Institute, Agriculture Research Center, Giza, Egypt \\ ${ }^{8}$ Plant Production Department, College of Food and Agricultural Sciences, King Saud University, P.O. Box 2460, \\ Riyadh 11451, Saudi Arabia
}

Correspondence should be addressed to Murugan Athiappan; amuruganpu@gmail.com

Received 23 January 2018; Accepted 8 April 2018; Published 16 May 2018

Academic Editor: Gamal Enan

Copyright (C) 2018 Kirubakaran Rangasamy et al. This is an open access article distributed under the Creative Commons Attribution License, which permits unrestricted use, distribution, and reproduction in any medium, provided the original work is properly cited.

Pesticide residual persistence in agriculture soil selectively increases the pesticide-degrading population and transfers the pesticidedegrading gene to other populations, leading to cross-resistance to a wide range of antibiotics. The enzymes that degrade pesticides can also catabolize the antibiotics by inducing changes in the gene or protein structure through induced mutations. The present work focuses on the pesticide-degrading bacteria isolated from an agricultural field that develop cross-resistance to antibiotics. This cross-resistance is developed through catabolic gene clusters present in an extrachromosomal plasmid. A larger plasmid (236.7 Kbp) isolated from Bacillus sp. was sequenced by next-generation sequencing, and important features such as $\alpha$ - $\beta$ hydrolase, DNA topoisomerase, DNA polymerase III subunit beta, reverse transcriptase, plasmid replication rep X, recombination U, transposase, and S-formylglutathione hydrolase were found in this plasmid. Among these, the $\alpha-\beta$ hydrolase enzyme is known for the degradation of organophosphate pesticides. The cloning and expression of the $\alpha$ - $\beta$ hydrolase gene imply nonspecific cleavage of antibiotics through a cross-resistance phenomenon in the host. The docking of $\alpha$ - $\beta$ hydrolase with a spectrum of antibiotics showed a high G-score against chloramphenicol (-3.793), streptomycin (-2.865), cefotaxime (-5.885), ampicillin ( -4.316$)$, and tetracycline $(-3.972)$. This study concludes that continuous exposure to pesticide residues may lead to the emergence of multidrug-resistant strains among the wild microbial flora.

\section{Introduction}

Plasmid-borne drug resistance and its persistence among soil bacteria cause great public health hazards. Although other genetic elements such as nonconjugative, mobilizable plasmids contribute to multidrug resistance [1-3], bacterial plasmid DNA also confers drug resistance $[4,5]$. Multidrug resistance is very common among soil bacteria that are exposed to pesticides [6,7]. Moreover, the indiscriminate use of pesticides favours the microbial population that can metabolize those pesticides. Higher exposure to pesticides enables bacteria to produce suitable enzymes for the degradation of pollutants. Consequently, pesticide-metabolizing populations tend to overgrow [8-10]. Pesticide-degrading bacteria metabolize the pesticides through hydrolytic cleavage for their carbon and energy sources [11, 12]. Degradation 
of pesticides may also occur through oxidation, reduction, hydrolysis, peroxidise, or oxygenase mechanisms $[13,14]$.

Enzymes produced by pesticide-degrading bacteria can catabolize drugs and other xenobiotics. Breaking $\mathrm{C}=\mathrm{C}$ bonds in the drug by nonspecific cleavage leads to cross-resistance to antibiotics $[15,16]$. This could be an explanation regarding how susceptible soil bacteria become multidrug resistant. A previous study on formaldehyde resistance with Enterobacteriaceae has shown high formaldehyde dehydrogenase activity leading to multidrug resistance through nonspecific activity $[17,18]$. A study conducted on formaldehyde dehydrogenase enzyme-mediated multidrug resistance provided the notion that cross-resistance is possible via nonspecific degradation. Another study proved that enzymes produced by soil bacteria in pesticide-contaminated soil can degrade other xenobiotics [19-21]. Assessing the catabolic properties of $\alpha$ $\beta$ hydrolase, an enzyme-degrading pesticide, would answer whether these enzymes play a role in multidrug resistance. It is very common among soil bacteria to adapt themselves to changing environmental conditions. Evolutionarily, bacteria in a stressed environment tend to produce putative enzymes via induced mutations that can degrade a wide range of xenobiotics [22].

Therefore, the present study aimed to understand the bacterial isolates with an extrachromosomal plasmid carrying pesticide-resistant genes that also confer the cross-resistance of multidrug resistance. In silico analyses were performed to understand the mechanism of cross-resistance via the $\alpha-\beta$ hydrolase enzyme.

\section{Materials and Methods}

2.1. Sample Collection. Soil samples were collected from up to $5 \mathrm{~cm}$ of the upper layer from different pesticides applied to an agriculture field located in the Salem district $\left(11.7794^{\circ} \mathrm{N}\right.$, $78.2034^{\circ} \mathrm{E}$ ), Tamil Nadu, India. The collected samples were transported to the laboratory and stored at $4^{\circ} \mathrm{C}$ until further analysis.

2.2. Plasmid Isolation and DNA Sequencing. Owing to the increased use of the plasmid, the sample was kept for plasmid enrichment by incubating with $1 \%$ pesticide (monocrotophos) supplemented medium for two days. The bacterial strains were isolated from the enriched sample, and it was found that Bacillus sp. MK-07 (KU510395.1) was predominant. Plasmid DNA (pMK-07) was isolated by the alkaline lysis method from the isolate [23]. The plasmid was treated with plasmid-safe, adenosine 5-triphosphate- (ATP-) dependent DNase to remove any genomic DNA contamination. The plasmid DNA was processed for library preparation using an Illumina Nextera XT DNA library preparation kit. SnapGene version 4.0.2 software was used to create a plasmid DNA map [24]. The library was sequenced on MiSeq using $2 \times 300 \mathrm{bp}$ to generate approximately $1 \mathrm{~GB}$ of data. The Draft assemblies of short Illumina sequence reads $(2 \times 300 \mathrm{MiSeq}$ library $)$ were analysed with a 4200-tape station system, Eurofins Genomics, Bangalore, India (Agilent Technologies, USA) [25].
2.3. Assembling the Plasmid DNA Sequence. Raw data were processed using Trimmomatic v 0.35 to remove adapter sequences, ambiguous reads (reads with unknown nucleotides "N" larger than 5\%), and low-quality sequences (reads with more than $10 \%$ quality thresholds (QV) $<20$ phred score). Clear sequences with a size of 1,073,566 ( $2 \times 300 \mathrm{bp})$ highquality reads were retained for further analysis and were used for de novo assembly $[2,26]$.

2.3.1. Gene Prediction and Functional Annotation. Sequences were predicted using prodigal with default parameters. In total, 225 genes were predicted with an average gene size of $816 \mathrm{bp}$, while the maximum and minimum sizes of the genes were $15,033 \mathrm{bp}$ and $105 \mathrm{bp}$, respectively $[27,28]$. Gene ontology annotations of the predicted [29] genes were determined by the Blast2GO program (https://www.Blast2GO.com). Gene ontology assignments were used to classify the functions of the predicted genes. Functional annotations of the genes were performed using BLASTx, part of the NCBIBlast-2.3.0 standalone tool. BLASTx was used to find the homologous sequence of genes against NR (nonredundant protein database) within Bacillus cereus (MK-07).

2.4. Phylogenetic Distinct Clades and Cloning of $\alpha-\beta$ Hydrolase Gene. The scaffold sample of plasmid (pMK-07) was aligned against plasmids of all the Bacillus species using BlastN. A Newick file was downloaded from the Blast Tree View and plotted further using an interactive tree of life (http://itol.embl.de/upload.cgi). Different parameters were adjusted according to the visualization requirements and were exported [29]. The $\alpha-\beta$ hydrolase gene was amplified using a gene-specific primer that was designed by the net primer (Premier Biosoft): $\alpha$ - $\beta$ hydrolase MK-FP: ATGGCTAAAGAAATGTTTGTGC and MK-RP: CGCACTAACTACTACTTCTGGT. The polymerase chain reaction mixtures $(50 \mu \mathrm{l})$ contained $10 \mu \mathrm{M}$ of each primer, PCR Invitrogen Master Mix (PCR buffer, 5 U of Taq polymerase, $10 \mu \mathrm{M}$ of BSA and $2 \mu \mathrm{l}$ of DNA). The thermocycling conditions included a denaturation step at $94^{\circ} \mathrm{C}$ for $3 \mathrm{~min}, 34$ amplification cycles of $94^{\circ} \mathrm{C}$ for $1 \mathrm{~min}, 57^{\circ} \mathrm{C}$ for $30 \mathrm{sec}$ and $72^{\circ} \mathrm{C}$ for $1 \mathrm{~min}$, and a final extension step for $8 \mathrm{~min}$ using an Eppendorf thermocycler (Eppendorf AG 22331). Electrophoresis was continued for $30 \mathrm{~min}$ at $100 \mathrm{~V}$ (Tarson electrophoresis unit). The size of the fragment was determined by comparing it with a $1 \mathrm{~kb}$ marker (NEB). The gene product was inserted into the $\mathrm{pXcm}$ vector using a ligation (Fermentas) enzyme.

The $\alpha$ - $\beta$ hydrolase gene was released from the $\mathrm{pXcm}$ vector using Bam $\mathrm{H} 1$ and Hind III. Expression of $\alpha-\beta$ hydrolase in E. coli DH5 $\alpha$ was achieved by subcloning it into pET-20. Transformation of recombinant DNA into E.coli/DH5 $\alpha$ : pET$20 \mathrm{~b}$ was carried out by standard methods [30]. Preliminary screening was performed based on the blue-white colonies on $\mathrm{x}$-gal medium, followed by PCR amplification of the $\alpha$ - $\beta$ hydrolase gene.

The recombinant bacterial strains were cultured overnight. The cells were harvested by centrifugation, and $\alpha-\beta$ hydrolase was recovered by sonication (10-15 min). Crude enzyme was electrophoresed by slope gel electrophoresis along with marker protein (SERVA) and then analysed. Next, 
$100 \mu \mathrm{l}$ of crude enzyme was mixed with $1 \mathrm{ml}$ of $30 \mu \mathrm{g} / \mathrm{ml}$ chloramphenicol, followed by incubation at $37^{\circ} \mathrm{C}$ for 48 hours. After the incubation, the metabolites were purified with twofold ethyl acetate and were evaporated under vacuum conditions. The extracted residues were dissolved in methanol to a volume of $2 \mathrm{ml}$ and were stored at $4^{\circ} \mathrm{C}$ until GC-FID analysis. The extract was analysed in an Agilent gas chromatograph (Model 7820A Series USA) equipped with a flame ionization detector [31].

2.5. Docking with Ligands. The Crystal Structure of $\alpha-\beta$ hydrolase (PDB ID: 1I6W) was retrieved from the protein data bank, and the ligands were downloaded from PubChem (http://www.ncbi.nlm.nih.gov/pccompound) with a PubChem ID (Table 1). The ligands were retrieved from the PubChem (http://www.ncbi.nlm.nih.gov/pccompound) database based on a literature survey. These compounds were subjected to ligand preparation by the Ligprep wizard application of the Maestro 9.2. Corrections such as the addition of hydrogen, $2 \mathrm{D}$ to $3 \mathrm{D}$ conversion, corrected bond lengths and bond angles, low energy structure, stereochemistries, and ring conformation, followed by minimization and optimization in the optimized potential for the liquid simulation force field [32-34] were performed. One conformation for each ligand was generated with other parameters used as the default in Maestro 9.2. Protein-ligand binding sites were predicted by the core-attachment based method (COACH) (http://zhanglab.ccmb.med.umich.edu/COACH/) using the meta-server approach. Complementary ligand binding site predictions were achieved using two comparative methods, TM-SITE and S-SITE, which recognize ligand binding templates from the BioLiP protein function database by binding-specific substructure and sequence profile comparisons. Docking was performed using the Glide software package (http://www.schrodinger.com/), which searches for favourable interactions between one or more typically small ligand molecules and a larger receptor molecule, usually a protein. The retrieved structures were subjected to the removal of water up to 5- $\AA$ distances, assigning lone pair electron atoms using a protein preparation wizard. The receptor grid was set up and generated to specify the binding pocket where the ligand binds using the receptor grid generation panel. Molecular docking of the prepared protein and ligand was carried out using Glide.

\section{Results and Discussion}

Continuous usage and accumulation of pesticide in the agricultural field lead to the development of cross-resistance to antibiotics among soil bacteria. Plasmid DNA (pMK07) from Bacillus sp. was sequenced and analysed using in silico tools, revealing that the plasmid DNA sequences and their relatedness lead to cross-resistance to pesticide and antibiotics. A triclosan-resistant bacterial population showing resistance to antimicrobial agents [35, 36] due to self-transmissible genes that can jump between plasmids and chromosomes $[37,38]$ and the accumulation of multidrug resistance genes in the soil bacterial community through horizontal gene transfer were common among pesticide
TABLE 1: List of ligands used for the docking analysis with $\alpha$ - $\beta$ hydrolase.

\begin{tabular}{lcc}
\hline Compounds & Molecular Weight & Pubchem ID \\
\hline Chloramphenicol & 323.132 & 5959 \\
Streptomycin & 581.574 & 19649 \\
Cefotaxime & 455.47 & 6540461 \\
Ampicillin & 349.41 & 6249 \\
Tetracycline & 444.435 & 54675776 \\
Monocrotophos & 223.16 & 5371562 \\
\hline
\end{tabular}

Note. http://www.ncbi.nlm.nih.gov/pccompound.

degraders $[39,40]$. Thus, these studies proved the phenomenon of cross-resistance in bacteria.

3.1. Plasmid DNA Sequence. The sequencing of plasmid pMK-07 of Bacillus species isolated from pesticide-exposed agriculture soil revealed that the plasmid shares genes from 6 different strains of Bacillus cereus (MSX-A12, NC7401, AH187, MSX-D12, IS845/00, and H3081.97), B. weihenstephanensis, and $S$. pneumoniae. Phylogenetic and dendrogram analyses of pMK-07 revealed that the plasmid shares $100 \%$ sequence similarity with Bacillus species (Figure 1), and the sequence was deposited in GenBank (KY940428.1).

In total, 225 genes were annotated from the plasmid, among which 221 genes found hits in the nucleotide database and four genes did not have a matching sequence in the database. Based on gene ontology annotation, the genes from the plasmid were categorized into three domains: biological process, cellular component, and molecular function. Similar categorization was performed for a plasmid (pNUC and p11601MD) that includes cellular and molecular component genes of a clinical multidrug resistance in S. typhimurium and Campylobacter jejuni strain 11601MD [2, 3] (Table 2).

3.2. Biological and Molecular Function of Genes. The genes responsible for the biological process of the bacteria, including the genes for spore formation, germination, sporulationspecific $\mathrm{N}$-acetylmuramoyl-L-alanine amidase, small, acidsoluble spore protein $\mathrm{C}_{5}$, and germination protein-Ger (x) C family protein, were found. These genes enable the bacteria to withstand the adverse conditions. The genes that are essential for DNA recombination were also present in the plasmid: site-specific recombinase, resolvase family, Tn1546 resolvase recombination protein $\mathrm{U}$, and integrase (Bacillus cereus) [4]. Thus, the plasmid underwent random recombination with different strains of Bacillus sp. The presence of genes such as thetraG/traD family, Flp pilus assembly protein, and $c p a \mathrm{~B}$ determines the horizontal gene transfer through conjugation [41, 42]. The presence of the ars $\mathrm{R}$ regulatory element makes the bacteria sense the presence of metal ions in the surroundings [43] and develop tolerance against the metal ions. The gene rep $X$ present in the plasmid is known for plasmid DNA replication. The presence of the IS3 and IS605 transposase families allows the DNA-mediated recombination and insertion of random sequences in the bacterial genome and extrachromosomal plasmid DNA. The presence of RNA-mediated DNA polymerase (reverse transcriptase) 
TABLE 2: Various genes present in the pMK-07 plasmid.

\begin{tabular}{|c|c|c|}
\hline ORF & Sequence description & Gene length (bp) \\
\hline AP007210.1_9 & transposase & 699 \\
\hline AP007210.1_11 & group II intron reverse transcriptase maturase & 1233 \\
\hline AP007210.1_14 & SAM-dependent methyltransferase & 1092 \\
\hline AP007210.1_18 & chitin-binding protein & 1275 \\
\hline AP007210.1_20 & F0F1 ATP synthase subunit alpha & 420 \\
\hline AP007210.1_21 & acid-soluble spore C5 & 216 \\
\hline AP007210.1_22 & chemotaxis protein & 819 \\
\hline AP007210.1_23 & Bacillolysin precursor & 1671 \\
\hline AP007210.1_28 & peptidase S8 & 762 \\
\hline AP007210.1_29 & precorrin-3B C(17)-methyltransferase & 468 \\
\hline AP007210.1_32 & conserved hypothetical protein & 144 \\
\hline AP007210.1_33 & integrase & 951 \\
\hline AP007210.1_37 & nucleotidyltransferase & 378 \\
\hline AP007210.1_38 & cytotoxin & 264 \\
\hline AP007210.1_40 & DNA-binding protein & 414 \\
\hline AP007210.1_41 & nucleotidyltransferase & 387 \\
\hline AP007210.1_43 & thiamine biosynthesis & 849 \\
\hline AP007210.1_50 & DNA polymerase III subunit beta & 1113 \\
\hline AP007210.1_56 & membrane protein & 285 \\
\hline AP007210.1_59 & MULTISPECIES: membrane & 264 \\
\hline AP007210.1_63 & S1 RNA binding domain & 984 \\
\hline AP007210.1_64 & inosine-uridine preferring nucleoside hydrolase family & 951 \\
\hline AP007210.1_65 & reverse transcriptase & 1647 \\
\hline AP007210.1_66 & conjugation family & 3501 \\
\hline AP007210.1_67 & conserved hypothetical plasmid & 387 \\
\hline AP007210.1_68 & conserved hypothetical plasmid & 1287 \\
\hline AP007210.1_69 & Plasmid replication repX & 1308 \\
\hline AP007210.1_70 & conserved hypothetical protein & 351 \\
\hline AP007210.1_72 & IS605 family & 1113 \\
\hline AP007210.1_78 & IS605 family transposase & 1335 \\
\hline AP007210.1_79 & surface layer & 1278 \\
\hline AP007210.1_81 & integrase core domain & 786 \\
\hline AP007210.1_82 & DNA-binding & 522 \\
\hline AP007210.1_84 & Flp pilus assembly & 861 \\
\hline AP007210.1_85 & SAF domain family & 852 \\
\hline AP007210.1_86 & type II secretion system & 1425 \\
\hline AP007210.1_87 & membrane & 933 \\
\hline AP007210.1_88 & conserved hypothetical protein & 867 \\
\hline AP007210.1_90 & conserved domain & 204 \\
\hline AP007210.1_91 & conserved domain & 207 \\
\hline AP007210.1_92 & IS605 family transposase & 1119 \\
\hline AP007210.1_95 & membrane protein & 624 \\
\hline AP007210.1_98 & sortase & 702 \\
\hline AP007210.1_99 & LPXTG-motif cell wall anchor domain & 528 \\
\hline AP007210.1_100 & ATP-binding protein & 189 \\
\hline AP007210.1_103 & conserved hypothetical protein & 252 \\
\hline AP007210.1_104 & cell division & 165 \\
\hline AP007210.1_106 & recombination $\mathrm{U}$ & 126 \\
\hline AP007210.1_113 & transposase for insertion sequence element $\mathrm{D}$ & 1275 \\
\hline AP007210.1_115 & transposon resolvase & 561 \\
\hline AP007210.1_116 & S-layer homology domain ribonuclease & 3396 \\
\hline AP007210.1_117 & barnase inhibitor & 276 \\
\hline
\end{tabular}


TABLe 2: Continued.

\begin{tabular}{|c|c|c|}
\hline ORF & Sequence description & Gene length (bp) \\
\hline AP007210.1_119 & putative membrane protein & 198 \\
\hline AP007210.1_124 & MULTISPECIES: ATPase & 924 \\
\hline AP007210.1_127 & prgI family & 351 \\
\hline AP007210.1_130 & reverse transcriptase & 1833 \\
\hline AP007210.1_132 & Reticulocyte binding & 3981 \\
\hline AP007210.1_133 & M23 M37 family & 2208 \\
\hline AP007210.1_139 & CAAX amino protease & 705 \\
\hline AP007210.1_141 & penicillin-binding partial & 414 \\
\hline AP007210.1_142 & membrane protein & 1146 \\
\hline AP007210.1_143 & thiol reductase thioredoxin & 483 \\
\hline AP007210.1_147 & family transcriptional regulator & 279 \\
\hline AP007210.1_148 & transcriptional regulator & 327 \\
\hline AP007210.1_149 & integrase recombinase & 1056 \\
\hline AP007210.1_150 & Transposase (plasmid) & 165 \\
\hline P007210.1_151 & conserved domain & 513 \\
\hline AP007210.1_152 & transcriptional regulator & 255 \\
\hline AP007210.1_153 & conserved domain & 156 \\
\hline AP007210.1_155 & type VII secretion & 1233 \\
\hline AP007210.1_156 & SMI1 KNR4 family & 450 \\
\hline AP007210.1_157 & lumazine binding domain & 381 \\
\hline AP007210.1_160 & transcriptional family & 300 \\
\hline AP007210.1_163 & transposase, partial & 630 \\
\hline AP007210.1_164 & transposon resolvase & 576 \\
\hline AP007210.1_165 & family transcriptional regulator & 846 \\
\hline AP007210.1_166 & transposon resolvase & 495 \\
\hline AP007210.1_168 & $\mathrm{N}$-acetylmuramoyl-L-alanine amidase & 699 \\
\hline AP007210.1_169 & phosphoglycerate mutase & 570 \\
\hline AP007210.1_170 & IS21 family & 1254 \\
\hline AP007210.1_171 & ATPase AAA & 759 \\
\hline AP007210.1_172 & Two-component response regulator & 864 \\
\hline AP007210.1_173 & glyoxalase family & 354 \\
\hline AP007210.1_174 & tn3 transposase DDE domain & 3054 \\
\hline AP007210.1_175 & site-specific recombinase & 627 \\
\hline AP007210.1_177 & XRE family transcriptional regulator & 231 \\
\hline AP007210.1_178 & alpha beta hydrolase & 732 \\
\hline AP007210.1_180 & cardiolipin synthetase & 1494 \\
\hline AP007210.1_181 & membrane yetF & 549 \\
\hline AP007210.1_183 & lipo & 486 \\
\hline AP007210.1_184 & stage $\mathrm{V}$ sporulation $\mathrm{AC}$ & 477 \\
\hline AP007210.1_185 & stage $\mathrm{V}$ sporulation $\mathrm{AD}$ & 1017 \\
\hline AP007210.1_186 & stage $\mathrm{V}$ sporulation $\mathrm{AE}$ & 351 \\
\hline AP007210.1_187 & NADH dehydrogenase & 207 \\
\hline AP007210.1_189 & ATP-dependent Clp protease proteolytic subunit & 582 \\
\hline AP007210.1_190 & resolvase & 552 \\
\hline AP007210.1_191 & spore germination $\mathrm{C}$ & 1134 \\
\hline AP007210.1_192 & spore germination & 657 \\
\hline AP007210.1_193 & spore germination family & 1536 \\
\hline AP007210.1_194 & phospholipase D competence helix-hairpin-helix domain & 222 \\
\hline AP007210.1_195 & transposase & 1500 \\
\hline
\end{tabular}


TABLe 2: Continued.

\begin{tabular}{|c|c|c|}
\hline ORF & Sequence description & Gene length (bp) \\
\hline AP007210.1_196 & transposase, partial & 1695 \\
\hline AP007210.1_197 & transposase for transposon & 741 \\
\hline AP007210.1_198 & transcriptional regulator & 357 \\
\hline AP007210.1_199 & S-(hydroxymethyl)glutathione dehydrogenase-like & 1116 \\
\hline AP007210.1_200 & S-glutathione hydrolase & 834 \\
\hline AP007210.1_201 & UDP-N-acetylmuramoylalanyl-D-glutamate--2,6-diaminopimelate ligase & 273 \\
\hline AP007210.1_202 & Glutamate--cysteine ligase & 2268 \\
\hline AP007210.1_204 & spore germination $\mathrm{XA}$ & 696 \\
\hline AP007210.1_205 & germination $\% 2 \mathrm{C}$ Ger $(\mathrm{x}) \mathrm{C}$ family & 1155 \\
\hline AP007210.1_206 & Spore germination & 1161 \\
\hline AP007210.1_207 & cell surface & 15033 \\
\hline AP007210.1_209 & Isochorismatase & 531 \\
\hline AP007210.1_211 & Two-component response regulator & 681 \\
\hline AP007210.1_212 & two-component sensor histidine kinase & 1848 \\
\hline AP007210.1_214 & conserved domain & 1011 \\
\hline AP007210.1_215 & inosine-uridine preferring nucleoside hydrolase family & 333 \\
\hline AP007210.1_217 & cell surface & 3711 \\
\hline AP007210.1_218 & cell surface & 6834 \\
\hline AP007210.1_219 & RNA-binding Hfq & 186 \\
\hline AP007210.1_220 & family transcriptional regulator & 294 \\
\hline AP007210.1_221 & 2-oxoglutarate dehydrogenase & 429 \\
\hline AP007210.1_225 & DNA topoisomerase I & 2664 \\
\hline
\end{tabular}

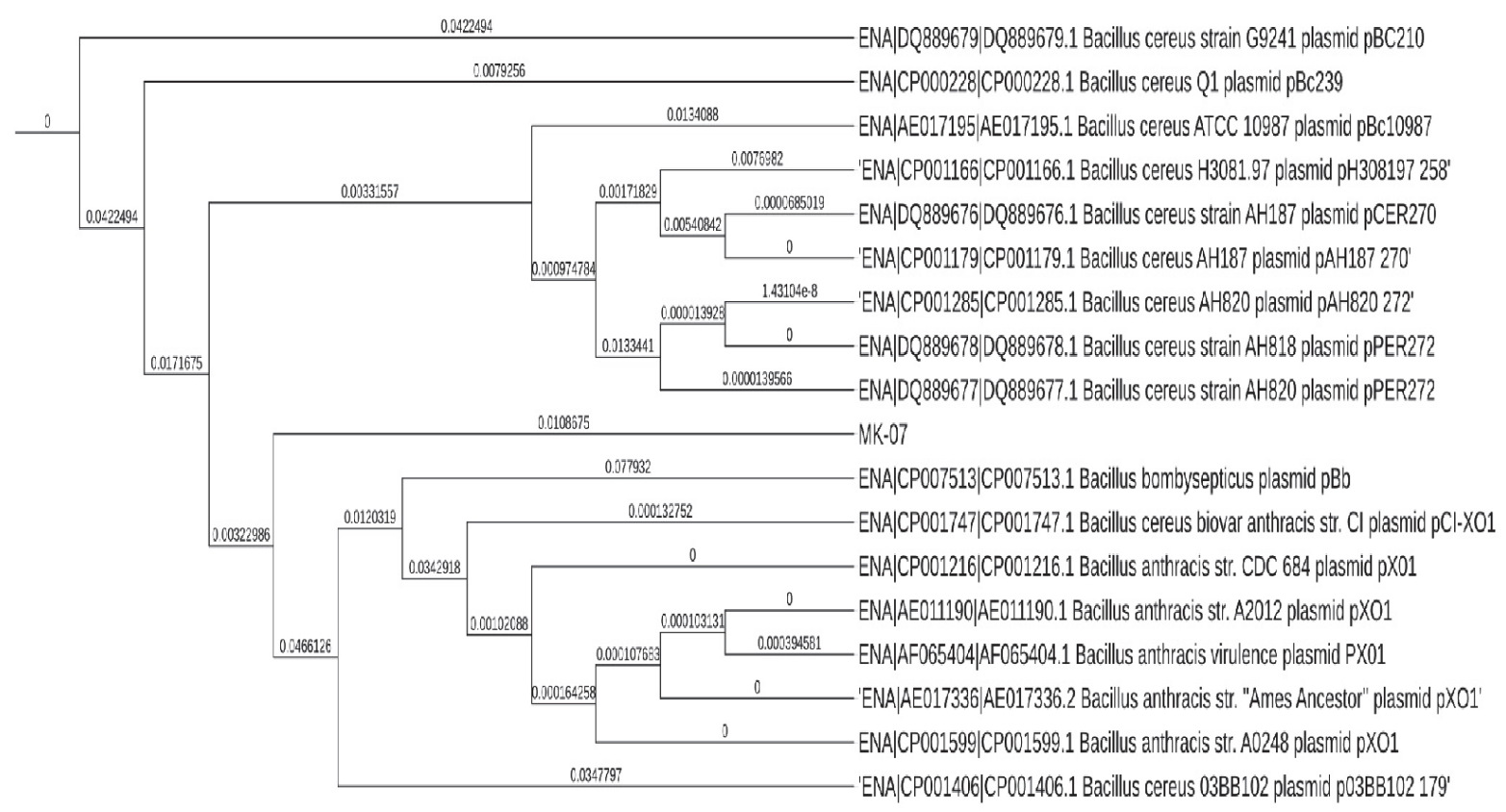

FIGURE 1: Homology cladogram of the plasmid DNA (sequence similarity of pMK-07 with Bacillus cereus). 


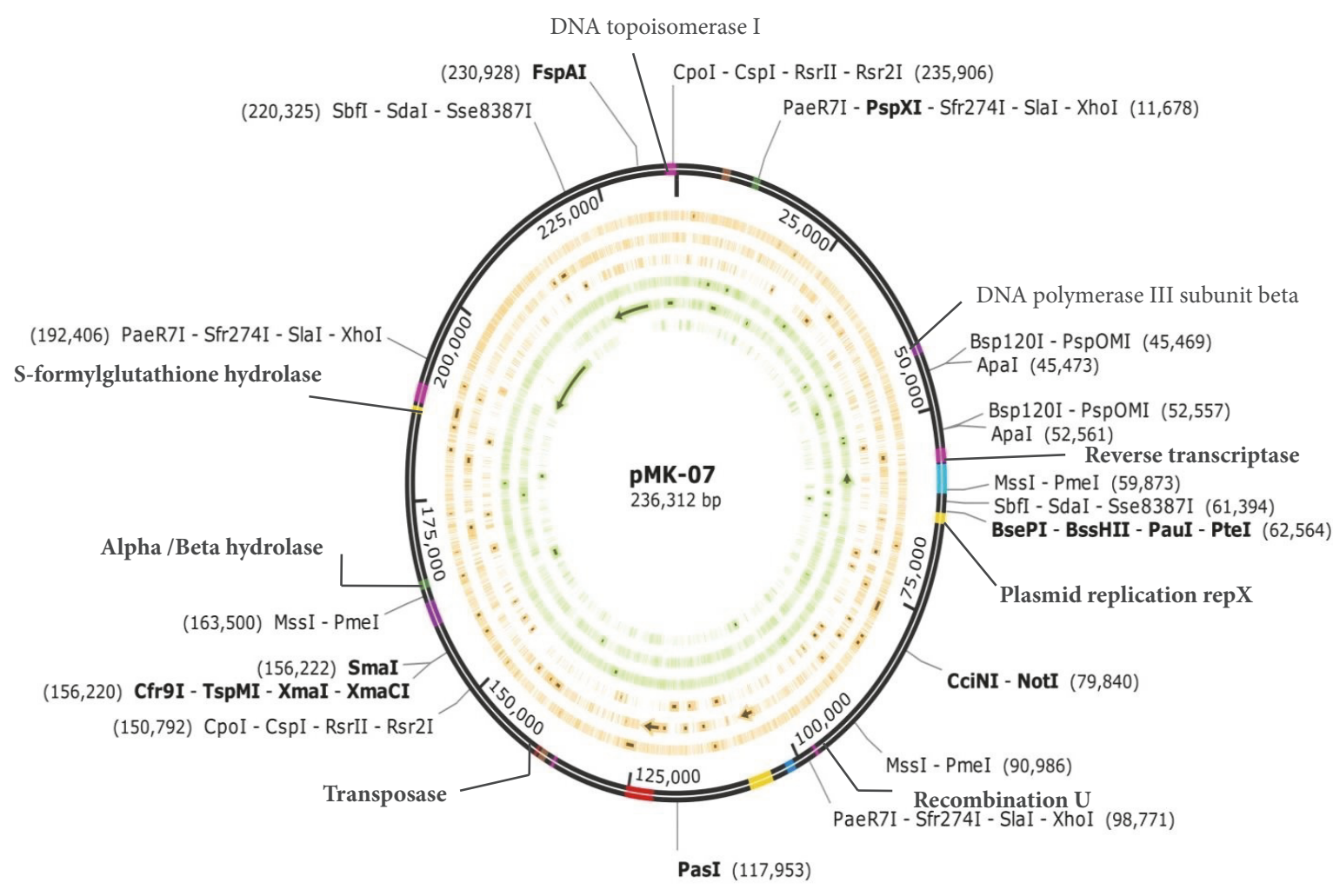

Top sequence ORF Frame

Bottom sequence ORF Frame

FIGURE 2: Gene map of plasmid DNA (pMK07) (distribution of $\alpha$ - $\beta$ hydrolase, DNA topoisomerase, DNA polymerase III subunit beta, reverse transcriptase, plasmid replication rep $\mathrm{X}$, recombination $\mathrm{U}$, transposase, and S-formylglutathione hydrolase).

genes indicated a history of involvement of viral transduction in the route of de novo plasmid generation.

DNA sequence analysis of the plasmid (pMK-07) DNA revealed the genes harboured in the novel de novo plasmid pMK-07 (Figure 2). Previous studies have shown that $\alpha$ $\beta$ hydrolase can hydrolyse a wide range of pesticides [44], and glutathione S-transferases (GSTs) were found to hydrolyse DDT [45, 46], organochlorine, and organophosphorus insecticides [47, 48]. Hydrolases and hypothetical protein existence in the plasmid suggest that it was a degradative plasmid, especially pesticides [49].

3.3. Cellular Components. It was observed that approximately $10 \%$ of genes are present in the plasmid codes for membrane components. The bacteria possess an LPXTG anchoring domain and sortase enzyme genes, whose coexistence affirms that the bacteria carrying this pMK-07 plasmid might also be pathogenic [50].

3.4. Evolution of Newer Characters. The increased uses of pesticides in the agricultural field serve as the selection pressure for the evolution of soil microbial flora. The bacteria in the soil tend to develop tolerance by acquiring new genes or plasmids from other bacterial sources by either vertical or horizontal gene transfer. Surprisingly, plasmids carry all the essential genes required for survival under adverse or stressed conditions, a finding that has been confirmed in C. jejuni and E. coli [51]. A similar observation was noted among plant pathogenic Gram-negative bacteria carrying genes essential for their infection in plants [52]. The results from our study agree with those in previous studies.

3.5. Cloning of the $\alpha-\beta$ Hydrolase Gene. The $\alpha-\beta$ hydrolase gene $(700 \mathrm{bp})$ was cloned into $\mathrm{pXcm}$ and was confirmed for their presence by running it on a $1.0 \%$ agarose gel. The expression of the gene for the $\alpha$ - $\beta$ hydrolase enzyme was also verified by SDS-PAGE, with the protein size corresponding to $45 \mathrm{kDa}$ (Figure 3 ). The $\alpha$ - $\beta$ hydrolase gene from the $\mathrm{pXcm}$ vector was then excised and subcloned into pET-20b. After transformation, the bacterial cells were screened on LB agar medium supplemented with ampicillin, IPTG, and X-gal. Plates showing white colonies (transformants; pET- $\alpha-\beta$ hydrolase plasmid) were picked and processed for further use.

3.6. Nonspecific Degradation of Chloramphenicol. It was predicted that $\alpha-\beta$ hydrolase could degrade chloramphenicol by nonspecific cleavage and break the $\mathrm{C}=\mathrm{C}$ bond in the ring 


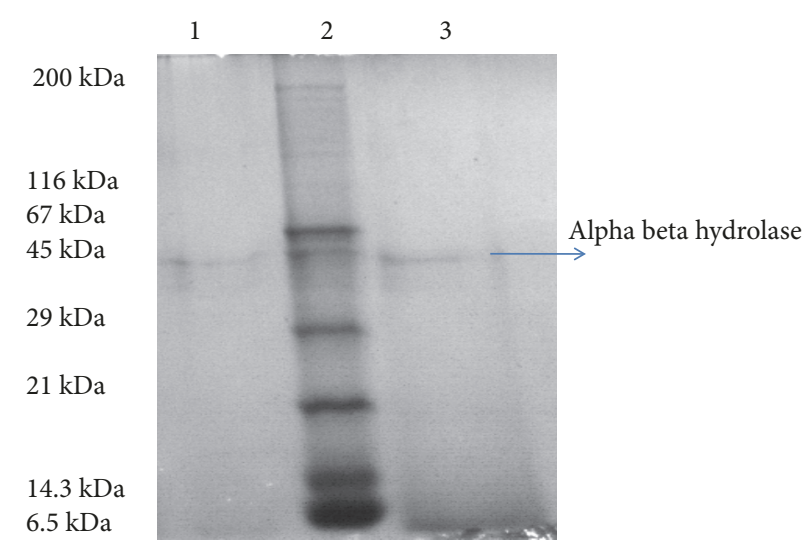

FIGURE 3: Characterization of $\alpha$ - $\beta$ hydrolase SDS-PAGE gels (lane-1: XL1 blue MRF'pET $\alpha$ - $\beta$ hydrolase gene expression; lane-2: SERVA unstained SDS-PAGE protein marker; lane-3: Bacillus sp. expression enzyme).

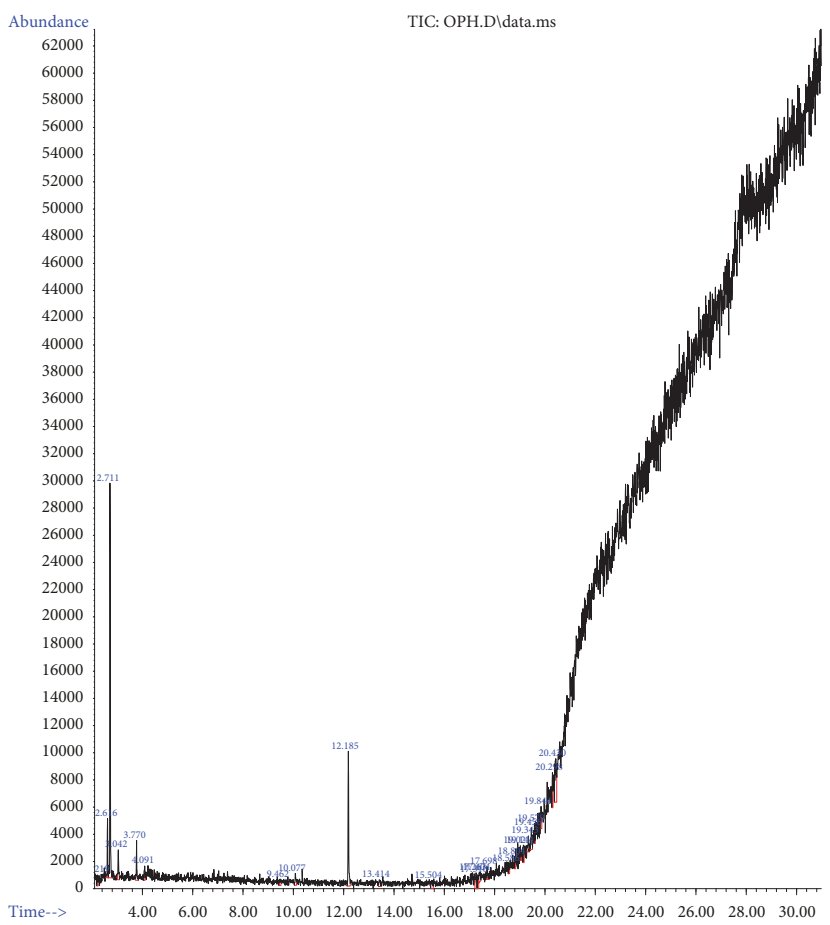

FIgURE 4: Nonspecific degradation of chloramphenicol by $\alpha-\beta$ hydrolase analysed by GC-MS (nonspecific degradation of antibiotics with $\alpha-\beta$ hydrolase analysed by GC-MS).

structure. Similar phenomena were observed in our study, when the cell lysate was mixed with $30 \mu \mathrm{g} / \mathrm{ml}$ of chloramphenicol, the lysate degraded the antibiotic, an observation that was proven through GC-MS analysis (Figure 4). GC-MS analysis revealed the breakdown compounds present in the pET $\alpha$ - $\beta$ hydrolase-treated sample (methane, oxybis dichloro, phenol, indole-2-one) (Figure 5). Based on previous works on the characterization of the catabolic ability of $\alpha-\beta$ hydrolase, the side chain of the nucleophilic amino acid residue of the enzyme attacks the electropositive carbon atom of the substrate [53-55]. The findings of the present study suggest that this bacterial strain, Bacillus sp. MK-07, which survived all the sublethal concentration of pesticides, potentially has the cross-resistance property to degrade the antibiotic chloramphenicol. The cross-resistance mechanisms may be due to ribosomal gene alteration to evolve cross-resistance [7].

3.7. Protein-Ligand Binding Site Prediction. The $\alpha-\beta$ hydrolase ligand binding sites were predicted by $\mathrm{COACH}$. The number of templates as the Cluster size was 69 , the confidence score (c-score) was 0.96 , and the binding residues were VAL9, 
<smiles>O=C(NC(CO)C(O)c1ccc([N+](=O)[O-])cc1)C(Cl)Cl</smiles>

Alpha beta hydrolase<smiles>Oc1ccccc1</smiles>

Phenol<smiles>O=[N+]([O-])c1ccc(CO)cc1</smiles>

[4-nitrophenyl] methanol

Figure 5: Pathway depicting chloramphenicol metabolism by $\alpha-\beta$ hydrolase (nonspecific degradation of chloramphenicol produces 4nitrophenyl methanol and phenol as intermediates).

TABLE 3: Docking score of $\alpha-\beta$ hydrolase with various ligands.

\begin{tabular}{lccc}
\hline Ligands/Pesticide & Gscore Kcal/mol & Number of Hydrogen Bonds & Amino Acid Interacting with Ligand \\
\hline Chloramphenicol & -3.793 & 4 & Gly11, Ile12, Ser 77 \\
Streptomycin & -2.865 & 3 & Gly13, Ile12 \\
Cefotaxime & -5.885 & 2 & Asn18, Ser 77 \\
Ampicillin & -4.316 & 2 & Asn18, Ser 77 \\
Tetracycline & -3.972 & 1 & Ile12 \\
Monocrotophos & -4.464 & 2 & Ile12, Ser 77 \\
\hline
\end{tabular}

HIS 10, VAL 74, ALA 75, HIS 76, ASP 103, ASP 133, and VAL 154 (Table 3).

3.7.1. Protein-Ligand Interaction. $\alpha-\beta$ hydrolase (PDB Id: $1 \mathrm{I} 6 \mathrm{~W}$ ) was docked with antibiotics (chloramphenicol, streptomycin, cefotaxime, ampicillin, and tetracycline) and the pesticide monocrotophos using Glide Maestro 9.2. Identification of the best-fit antibiotic was performed based on the G-score and number of hydrogen bonds involved. A similar study showed that a sublethal concentration of herbicides would result in the development of multidrug resistance among soil bacteria [56]. Because of the toxicity of the pesticide, the bacteria develop resistance, which allows them to adapt to such components [57].

The strong interaction of $\alpha-\beta$ hydrolase with chloramphenicol showed a Glide score of $-3.793 \mathrm{Kcal} / \mathrm{mol}$. Chloramphenicol interacts with ILE 12, GLY 11, and SER 77 with distances of $2.214 \AA$ and $2.176 \AA, 2.255 \AA$, and $2.430 \AA$, respectively, at the active site of the enzyme (Figure 6. I.a). In the surface view of the $\alpha$ - $\beta$ hydrolase-chloramphenicol complex, chloramphenicol is highlighted with green (Figure 6. I.b). In the $2 \mathrm{D}$ interaction of the $\alpha-\beta$ hydrolase-chloramphenicol complex, the purple dotted line represents the hydrogen bond with the side chain (Figure 6. I.c and Table 3).

The surface view of $\alpha-\beta$ hydrolase with streptomycin showed a Glide score of $-2.865 \mathrm{Kcal} / \mathrm{mol}$ and interaction of streptomycin with ILE 12, GLY 13, and HIS 76 at the active site (Figure 6 . II.a). In the surface view of the $\alpha-\beta$ hydrolasestreptomycin complex, streptomycin is highlighted in green (Figure 6. II.b). In the $2 \mathrm{D}$ interaction of the $\alpha-\beta$ hydrolasestreptomycin complex, the purple dotted line represents the hydrogen bond with the side chain (Figure 6. II.c and Table 3 ).

The interaction formed between $\alpha-\beta$ hydrolase and cefotaxime showed a Glide score of $-5.885 \mathrm{Kcal} / \mathrm{mol}$. This interaction of cefotaxime at the active site of the enzyme with ASN 18 and with SER 77 revealed distances of $2.077 \AA$ and $2.022 \AA$, respectively (Figure 6. III.a). In the surface view of the interaction of the $\alpha-\beta$ hydrolase-cefotaxime complex, cefotaxime is highlighted in green (Figure 6. III.b). In the $2 \mathrm{D}$ interaction of the $\alpha$ - $\beta$ hydrolase-cefotaxime complex, the purple dotted line represents the hydrogen bond with the side chain (Figure 6. III.c and Table 3).

The interaction formed between $\alpha$ - $\beta$ hydrolase and ampicillin showed a Glide score of $-4.316 \mathrm{Kcal} / \mathrm{mol}$. This interaction involves two hydroxyl bonds between the hydrogen atom of ampicillin with ASN 18 and an oxygen atom of ampicillin with SER 77 with a distance of $1.987 \AA$ and $2.181 \AA$ (Figure 6. IV.a). In the surface view of the $\alpha$ - $\beta$ hydrolase-ampicillin complex, ampicillin is highlighted in green (Figure 6. IV.b). In the $2 \mathrm{D}$ interaction of the $\alpha-\beta$ hydrolase-ampicillin complex, the purple dotted line represents the hydrogen bond with the side chain (Figure 6. IV.c and Table 3). 

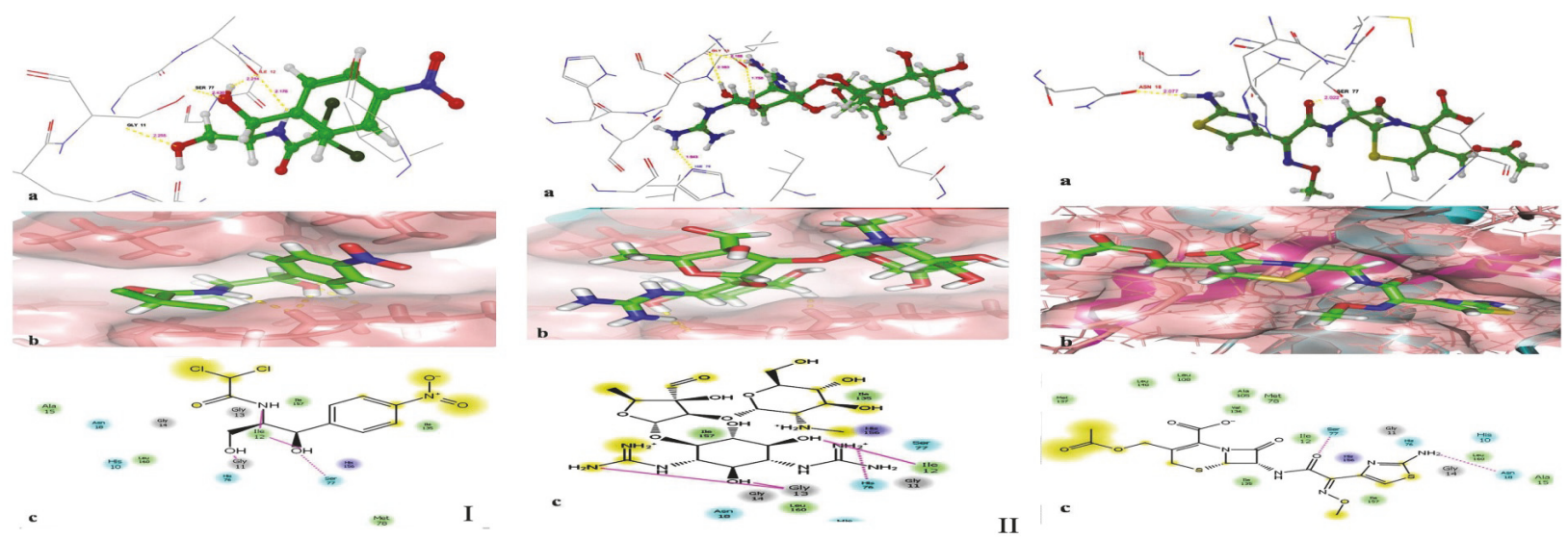

II
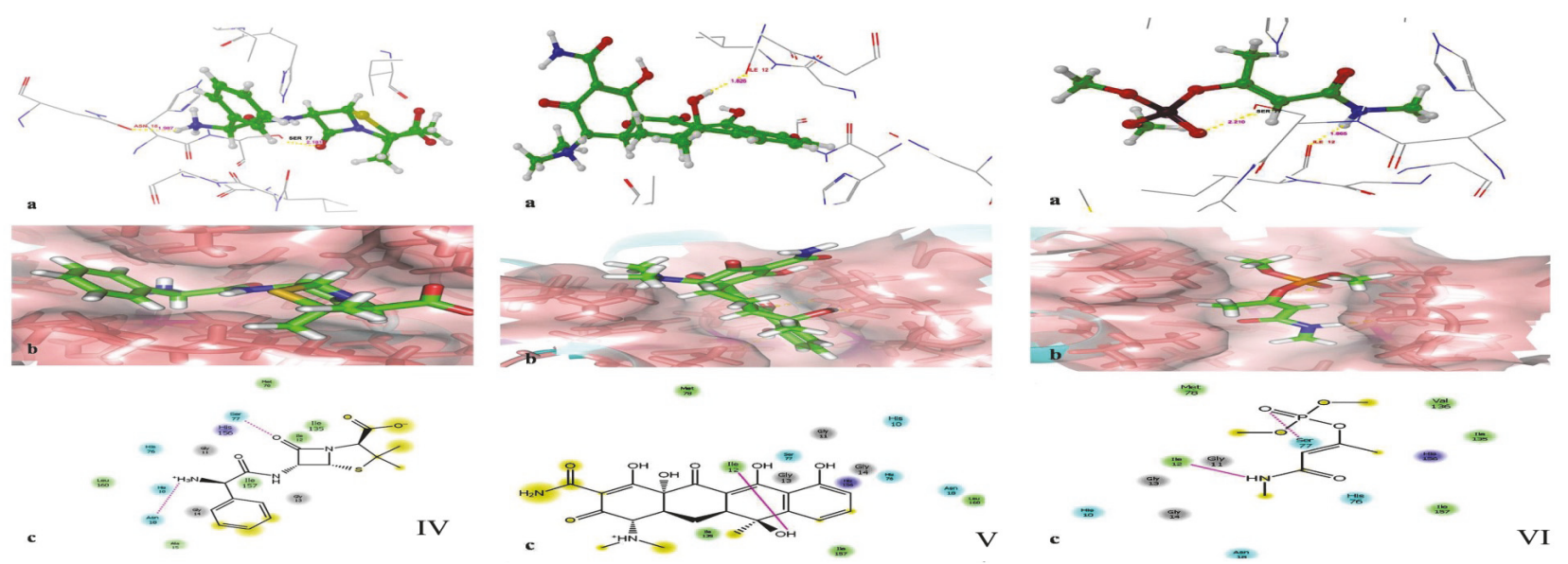

FIGURE 6: Docking of $\alpha-\beta$ hydrolase with antibiotics. Interaction of GLY 11 and SER 77 with the OH group. Similarly, ILE 12 binds to NH and OH; II: interaction of ILE 12 with the OH group. HIE 76 binds to NH, and GLY 13 binds to both the NH and OH groups; III: binding interaction of ASN 18 with the $\mathrm{OH}$ group and SER 77 with the NH group; IV: interaction of ASN 18 with the $\mathrm{NH}_{3}$ group. SER 77 binds to the OH group; V: docking interaction of ILE 12 binding to the OH group; VI: docking interaction of ILE 12 binding to the NH group. SER 77 interacts with the $\mathrm{OH}$ group.

The interaction formed between $\alpha-\beta$ hydrolase and tetracycline showed a Glide score of $-3.972 \mathrm{Kcal} / \mathrm{mol}$. This interaction involved ILE 12 hydroxyl bonds between tetracycline and ILE 12 with a distance of $1.826 \AA$ (Figure 6. V.a). In the surface view of the $\alpha-\beta$ hydrolase-tetracycline complex, tetracycline is highlighted in green (Figure 6. V.b). In the $2 \mathrm{D}$ interaction of the $\alpha-\beta$ hydrolase-tetracycline complex, the purple dotted line represents the hydrogen bond with the side chain (Figure 6. V.c and Table 3).

The interaction of $\alpha-\beta$ hydrolase with monocrotophos showed a Glide score of $-4.464 \mathrm{Kcal} / \mathrm{mol}$. The monocrotophos interacts with ILE 12 and with SER 77 with a distance of $1.865 \AA$ and $2.210 \AA$ at the active site of the enzyme (Figure 6. VI.a). In the surface view of the $\alpha-\beta$ hydrolasemonocrotophos complex, monocrotophos is highlighted in green (Figure 6. VI.b). In the 2D interaction of the $\alpha$ $\beta$ hydrolase-monocrotophos complex, the pink dotted line represents the hydrogen bond with the side chain (Figure 6 VI.c and Table 3). Among these antibiotics, based on the docking scores, it can be concluded that all five antibiotics can be degraded through nonspecific cleavage by $\alpha-\beta$ hydrolase.
A similar observation in the present study has proven that the hydrolase enzymes could bind with chloramphenicol and hydrolyse it into a nontoxic substance $[58,59]$. Excessive pesticide usage resulted in the accumulation of pesticide residues in crops, soils, and the biosphere, creating ecological stress $[60,61]$.

\section{Conclusion}

The present work focuses on the pesticide-degrading bacteria isolated from an agricultural field that develop crossresistance to antibiotics. This cross-resistance is developed through catabolic gene clusters present in an extra chromosomal plasmid. It can be concluded from the current study that existence of pesticide-resistant plasmids among soil bacteria can also confer cross-resistance to antibiotics through natural selection exerted by pesticide accumulation in the agriculture field. The enzymes that degrade pesticides can also catabolize the antibiotics by inducing changes in the gene or protein structure through induced mutations. Hence, an alternate way to control pests may 
pave the way for limiting the emergence of multidrug resistance.

\section{Conflicts of Interest}

All the authors declare no conflicts of interest.

\section{Acknowledgments}

The authors acknowledge the Periyar University, Salem, Tamil Nadu, India, for a University Research Fellowship and DSTFIST Grant no. SR/FST/LSI-640/2015(c). The authors would also like to thank SERB-DST GoI vide Grant no. YSS/ 2014/000590 for providing financial support. The authors would also like to extend their sincere appreciation to the Deanship of Scientific Research at King Saud University for funding this Research Group (RGP-271).

\section{References}

[1] Y. Wang, "Spatial distribution of high copy number plasmids in bacteria," Plasmid, vol. 91, pp. 2-8, 2017.

[2] M. Oliva, R. Monno, P. D’Addabbo et al., "A novel group of IncQ1 plasmids conferring multidrug resistance," Plasmid, vol. 89, pp. 22-26, 2017.

[3] M. D. Crespo, E. Altermann, J. Olson, W. G. Miller, K. Chandrashekhar, and S. Kathariou, "Novel plasmid conferring kanamycin and tetracycline resistance in the turkey-derived Campylobacter jejuni strain 11601MD," Plasmid, vol. 86, pp. 3237, 2016.

[4] K. Smalla, S. Jechalke, and E. M. Top, "Plasmid detection, characterization and ecology," Microbiology Spectrum, vol. 3, no. 1, pp. 1-21, 2015.

[5] R. Anjum and N. Krakat, "A review: improper antibiotic utilization evokes the dissemination of resistances in biotic environments - a high risk of health hazards," Pharmaceutica Analytica Acta, vol. 6, no. 12, 2015.

[6] S. Shafiani and A. Malik, "Tolerance of pesticides and antibiotic resistance in bacteria isolated from wastewater-irrigated soil," World Journal of Microbiology and Biotechnology, vol. 19, no. 9, pp. 897-901, 2003.

[7] J. Bergman, "Does the acquisition of antibiotic and pesticide resistance provide evidence for evolution?" Journal of Creation, vol. 1, no. 17, pp. 26-32, 2003.

[8] R. Kirubakaran, A. Murugan, P. Chinnathambi, and J. A. Parray, "Influence of residual pesticide on plant growth promoting bacteria isolated from agriculture field," Journal of Basic Applied Plant Sciences, vol. 1, no. 2, p. 110, 2017.

[9] J. Davison, "Genetic exchange between bacteria in the environment," Plasmid, vol. 42, no. 2, pp. 73-91, 1999.

[10] C. Smillie, M. P. Garcillan-Barcia, M. V. Francia, E. P. Rocha, and F. de la Cruz, "Mobility of Plasmids," Microbiology and Molecular Biology Reviews, vol. 74, no. 3, pp. 434-452, 2010.

[11] S. J. Sørensen, M. Bailey, L. H. Hansen, N. Kroer, and S. Wuertz, "Studying plasmid horizontal transfer in situ: A critical review," Nature Reviews Microbiology, vol. 3, no. 9, pp. 700-710, 2005.

[12] L. Yao, X. Jia, J. Zhao et al., "Degradation of the herbicide dicamba by two sphingomonads via different O-demethylation mechanisms," International Biodeterioration \& Biodegradation, vol. 104, pp. 324-332, 2015.
[13] S. Xie, R. Wan, Z. Wang, and Q. Wang, "Atrazine biodegradation by Arthrobacter strain DAT1: Effect of glucose supplementation and change of the soil microbial community," Environmental Science and Pollution Research, vol. 20, no. 6, pp. 4078-4084, 2013.

[14] B. Ramakrishnan, M. Megharaj, K. Venkateswarlu, N. Sethunathan, and R. Naidu, "Mixtures of environmental pollutants: Effects on microorganisms and their activities in soils," Reviews of Environmental Contamination and Toxicology, vol. 211, pp. 63-120, 2011.

[15] R. Capita, F. Riesco-Peláez, A. Alonso-Hernando, and C. Alonso-Calleja, "Exposure of Escherichia coli ATCC 12806 to Sublethal Concentrations of Food-Grade Biocides Influences Its Ability To Form Biofilm, Resistance to Antimicrobials, and Ultrastructure," Applied and Environmental Microbiology, vol. 4, no. 80, pp. 1268-1280, 2014.

[16] R. J. W. Lambert, "Comparative analysis of antibiotic and antimicrobial biocide susceptibility data in clinical isolates of methicillin-sensitive Staphylococcus aureus, methicillinresistant," Journal of Applied Microbiology, vol. 97, no. 4, pp. 699-711, 2004.

[17] H. T. Tu, F. Silvestre, N. T. Phuong, and P. Kestemont, "Effects of pesticides and antibiotics on penaeid shrimp with special emphases on behavioral and biomarker responses," Environmental Toxicology and Chemistry, vol. 29, no. 4, pp. 929-938, 2010.

[18] M. Heinzel, "Phenomena of biocide resistance in microorganisms," International Biodeterioration \& Biodegradation, vol. 41, no. 3-4, pp. 225-234, 1998.

[19] W. Zhang, F. Jiang, and J. Ou, "Global pesticide consumption and pollution: with China as a focus," International Academy of Ecology Environment Sciences, vol. 1, no. 2, pp. 125-144, 2011.

[20] C. Chen, C. Huang, M. M. Wu et al., "Multidrug Resistance 1 Gene Variants, Pesticide Exposure, and Increased Risk of DNA Damage," BioMed Research International, vol. 2014, Article ID 965729, 9 pages, 2014.

[21] D. R. Livingstone, "The fate of organic xenobiotics in aquatic ecosystems: Quantitative and qualitative differences in biotransformation by invertebrates and fish," Comparative Biochemistry and Physiology - A Molecular and Integrative Physiology, vol. 120, no. 1, pp. 43-49, 1998.

[22] K. Rangasamy, M. Athiappan, N. Devarajan et al., "Pesticide degrading natural multidrug resistance bacterial flora," Microbial Pathogenesis, vol. 114, pp. 304-310, 2018.

[23] H. C. Bimboim and J. Doly, "A rapid alkaline extraction procedure for screening recombinant plasmid DNA," Nucleic Acids Research, vol. 7, no. 6, pp. 1513-1523, 1979.

[24] L. Zhang, S. Wong, O. King, and F. P. Roth, "Predicting co-complexed protein pairs using genomic and proteomic data integration," BMC Bioinformatics, vol. 5, no. 59, pp. 1-9, 2004.

[25] A. Carattoli, E. Zankari, A. Garciá-Fernández et al., "In Silico detection and typing of plasmids using plasmidfinder and plasmid multilocus sequence typing," Antimicrobial Agents and Chemotherapy, vol. 58, no. 7, pp. 3895-3903, 2014.

[26] A. M. Bolger, M. Lohse, and B. Usadel, “Trimmomatic: a flexible trimmer for Illumina sequence data," Bioinformatics, vol. 30, no. 15, pp. 2114-2120, 2014.

[27] S. Nurk, A. Bankevich, D. Antipov et al., "Assembling singlecell genomes and mini-metagenomes from chimeric MDA products," Journal of Computational Biology, vol. 20, no. 10, pp. 714737, 2013 
[28] R. K. Aziz, D. Bartels, A. Best et al., “The RAST Server: rapid annotations using subsystems technology," BMC Genomics, vol. 9, no. 75, pp. 1-15, 2008.

[29] C. J. Brown, D. Sen, H. Yano et al., "Diverse broad-host-range plasmids from freshwater carry few accessory genes," Applied and Environmental Microbiology, vol. 79, no. 24, pp. 7684-7695, 2013.

[30] M. R. Green and J. Sambrook, Molecular Cloning: A Laboratory Manual, vol. 1, Cold Spring Harbor Laboratory Press, 4 edition, 2012.

[31] S. Z. Hussaini, M. Shaker, and M. A. Iqbal, "Isolation of bacterial for degradation of selected pesticides," Advanced Biomedical Research, vol. 4, no. 3, pp. 82-85, 2013.

[32] W. L. Jorgensen and J. Tirado-Rives, “The OPLS [optimized potentials for liquid simulations] potential functions for proteins, energy minimizations for crystals of cyclic peptides and crambin," Journal of the American Chemical Society, vol. 110, no. 6, pp. 1657-1666, 1988.

[33] W. L. Jorgensen, D. S. Maxwell, and J. Tirado-Rives, "Development and testing of the OPLS all-atom force field on conformational energetics and properties of organic liquids," Journal of the American Chemical Society, vol. 118, no. 45, pp. 11225-11236, 1996.

[34] D. Shivakumar, J. Williams, Y. Wu, W. Damm, J. Shelley, and W. Sherman, "Prediction of absolute solvation free energies using molecular dynamics free energy perturbation and the opls force field," Journal of Chemical Theory and Computation, vol. 6, no. 5, pp. 1509-1519, 2010.

[35] M. A. Webber, R. N. Whitehead, M. Mount, N. J. Loman, M. J. Pallen, and L. J. V. Piddock, "Parallel evolutionary pathways to antibiotic resistance selected by biocide exposure," Journal of Antimicrobial Chemotherapy, vol. 70, no. 8, Article ID dkv109, pp. 2241-2248, 2015.

[36] S. P. Bernier and M. G. Surette, "Concentration-dependent activity of antibiotics in natural environments," Frontier Microbiolology, vol. 4, no. 20, pp. 1-14, 2013.

[37] L. Walkup, “Junk DNA: Evolutionary Discards or Gods Tools?” Journal of Creation, vol. 14, no. 2, pp. 18-30, 2000.

[38] E. Top, I. De Smet, W. Verstraete, R. Dijkmans, and M. Mergeay, "Exogenous isolation of mobilizing plasmids from polluted soils and sludges," Applied and Environmental Microbiology, vol. 60, no. 3, pp. 831-839, 1994.

[39] B. G. Spratt, "Resistance to antibiotics mediated by target alterations," Science, vol. 264, no. 5157, pp. 388-393, 1994.

[40] C. M. Thomas and K. M. Nielsen, "Mechanisms of, and barriers to, horizontal gene transfer between bacteria," Nature Reviews Microbiology, vol. 3, no. 9, pp. 711-721, 2005.

[41] H. Heuer and K. Smalla, "Plasmids foster diversification and adaptation of bacterial populations in soil," FEMS Microbiology Reviews, vol. 36, no. 6, pp. 1083-1104, 2012.

[42] S. P. Djordjevic, H. W. Stokes, and P. R. Chowdhury, "Mobile elements, zoonotic pathogens and commensal bacteria: Conduits for the delivery of resistance genes into humans, production animals and soil microbiota," Frontiers in Microbiology, vol. 4, no. 86, pp. 1-12, 2013.

[43] C.-H. Gao, M. Yang, and Z.-G. He, "Characterization of a novel ArsR-like regulator encoded by Rv2034 in mycobacterium tuberculosis," PLoS ONE, vol. 7, no. 4, Article ID e36255, 2012.

[44] I. R. Montella, R. Schama, and D. Valle, "The classification of esterases: an important gene family involved in insecticide resistance - A review," Memórias do Instituto Oswaldo Cruz, vol. 107, no. 4, pp. 437-449, 2012.
[45] A. H. Tang and C. P. Tu, "Biochemical characterization of Drosophila glutathione S-transferases D1 and D21," The Journal of Biological Chemistry, vol. 269, no. 45, pp. 27876-27884, 1994.

[46] W. Y. Low, S. C. Feil, H. L. Ng et al., "Recognition and detoxification of the insecticide DDT by drosophila melanogaster glutathione S-transferase D1, Journal of Molecular Biology, vol. 399, no. 3, pp. 358-366, 2010.

[47] A. J. Ketterman, C. Saisawang, and J. Wongsantichon, "Insect glutathione transferases," Drug Metabolism Reviews, vol. 43, no. 2, pp. 253-265, 2011.

[48] R. H. Ffrench-Constant, "The molecular genetics of insecticide resistance," Genetics, vol. 194, no. 4, pp. 807-815, 2013.

[49] J. G. Vontas, G. J. Small, and J. Hemingway, "Glutathione Stransferases as antioxidant defence agents confer pyrethroid resistance in Nilaparvata lugens," Biochemical Journal, vol. 357, no. 1, pp. 65-72, 2001.

[50] J. W. Pridgeon and P. H. Klesius, "Major bacterial diseases in aquaculture and their vaccine development," CAB Reviews: Perspectives in Agriculture, Veterinary Science, Nutrition and Natural Resources, vol. 7, no. 48, pp. 1-16, 2012.

[51] S. Zhao, G. H. Tyson, Y. Chen et al., "Whole-genome sequencing analysis accurately predicts antimicrobial resistance phenotypes in Campylobacter spp," Applied and Environmental Microbiology, vol. 82, no. 2, pp. 459-466, 2016.

[52] N. Eltlbany, Z.-Z. Prokscha, M. P. Castañeda-Ojeda et al., "A new bacterial disease on Mandevilla sanderi, caused by Pseudomonas savastanoi: Lessons learned for bacterial diversity studies," Applied and Environmental Microbiology, vol. 78, no. 23, pp. 8492-8497, 2012.

[53] E. Diaz and K. N. Timmis, "Identification of functional residues in a 2-hydroxymuconic semialdehyde hydrolase. A new member of the $\alpha / \beta$ hydrolase-fold family of enzymes which cleaves carbon-carbon bonds," The Journal of Biological Chemistry, vol. 270, no. 11, pp. 6403-6411, 1995.

[54] F. Fischer, S. Künne, and S. Fetzner, "Bacterial 2,4-dioxygenases: New members of the $\alpha / \beta$ hydrolase-fold superfamily of enzymes functionally related to serine hydrolases," Journal of Bacteriology, vol. 181, no. 18, pp. 5725-5733, 1999.

[55] D. Liu, L. Wang, H. Zhai et al., "A Novel $\alpha / \beta$-Hydrolase Gene IbMas Enhances Salt Tolerance in Transgenic Sweetpotato," PLoS ONE, vol. 9, no. 12, p. el15128, 2014.

[56] B. Kurenbach, D. Marjoshi, C. F. Amábile-Cuevas et al., "Sublethal exposure to commercial formulations of the herbicides dicamba, 2,4-dichlorophenoxyacetic acid, and Glyphosate cause changes in antibiotic susceptibility in Escherichia coli and Salmonella enterica serovar Typhimurium," mBio, vol. 6, no. 2, Article ID e00009-15, 2015.

[57] D. H. Nies and S. Silver, "Ion efflux systems involved in bacterial metal resistances," Journal of Industrial Microbiology and Biotechnology, vol. 14, no. 2, pp. 186-199, 1995.

[58] N. Neti and V. Zakkula, "In silico structural analysis and binding of organophosphorus hydrolase of Kocuria sp with chlorpyrifos," International Journal of Computer Applications, vol. 66, no. 5, pp. 0975-8887, 2013.

[59] K. Rangasamy, M. Athiappan, N. Devarajan, and J. A. Parray, "Emergence of multi drug resistance among soil bacteria exposing to insecticides," Microbial Pathogenesis, vol. 105, pp. 153-165, 2017.

[60] C.-L. Qiao, Y.-C. Yan, H. Y. Shang, X. T. Zhou, and Y. Zhang, "Biodegradation of pesticides by immobilized recombinant Escherichia coli," Bulletin of Environmental Contamination and Toxicology, vol. 71, no. 2, pp. 370-374, 2003. 
[61] J. S. Seo, Y. S. Keum, R. M. Harada, and Q. X. Li, "Isolation and Characterization of Bacteria Capable of Degrading Polycyclic Aromatic Hydrocarbons (PAHs) and Organophosphorus Pesticides from PAH-Contaminated Soil in Hilo, Hawaii," Journal of Agricultural and Food Chemistry, vol. 55, no. 14, pp. 5383-5389, 2007. 


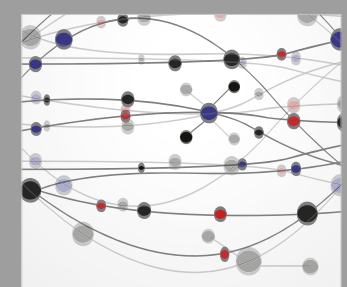

The Scientific World Journal
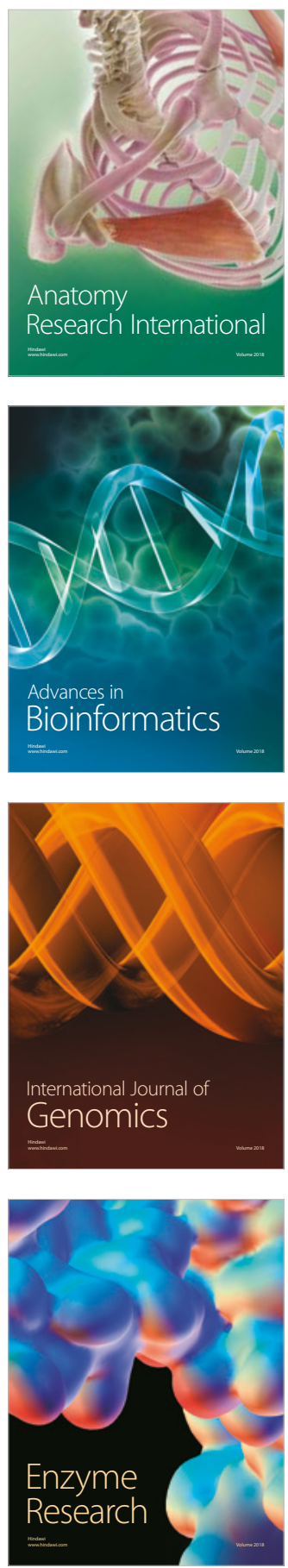
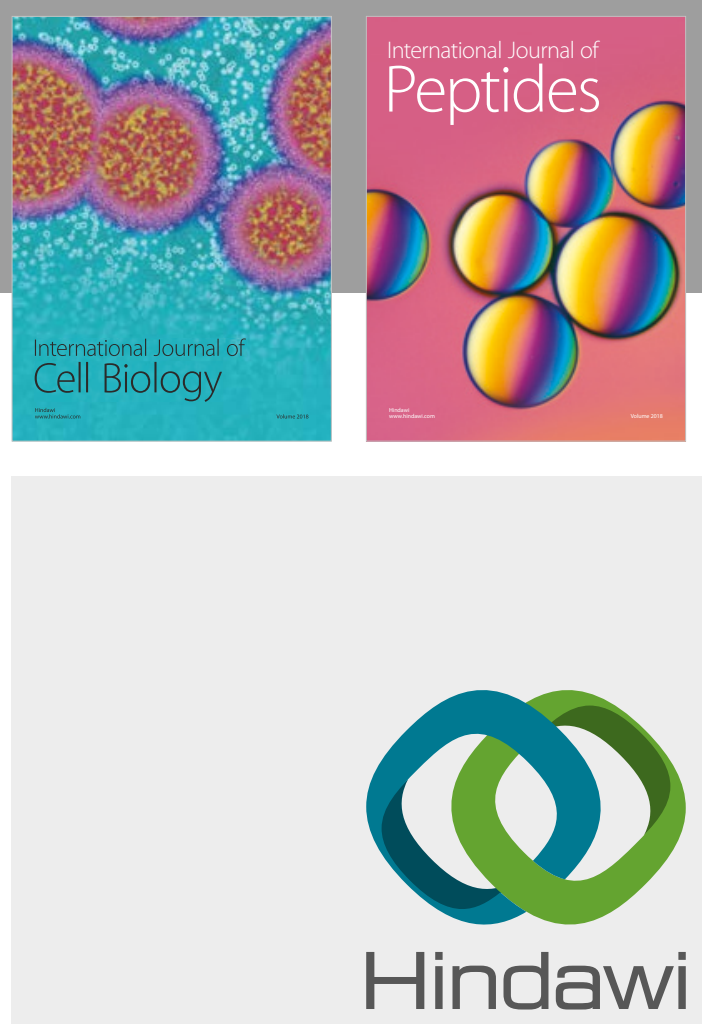

Submit your manuscripts at

www.hindawi.com
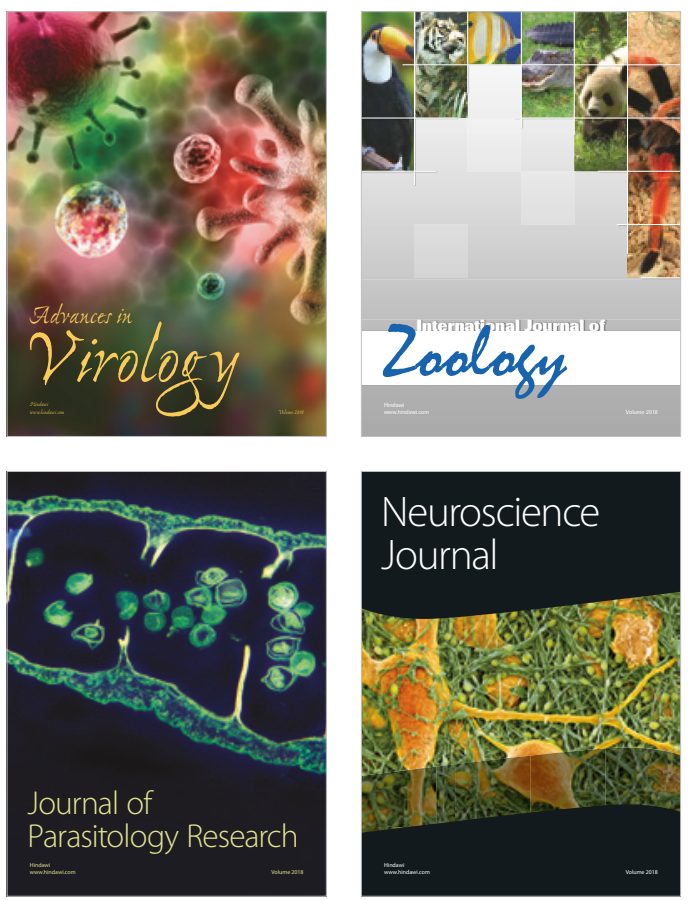
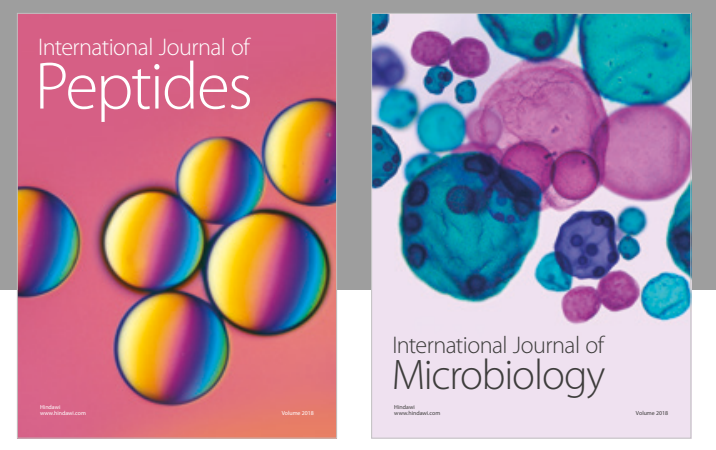

nternational Journal of Microbiology
Journal of
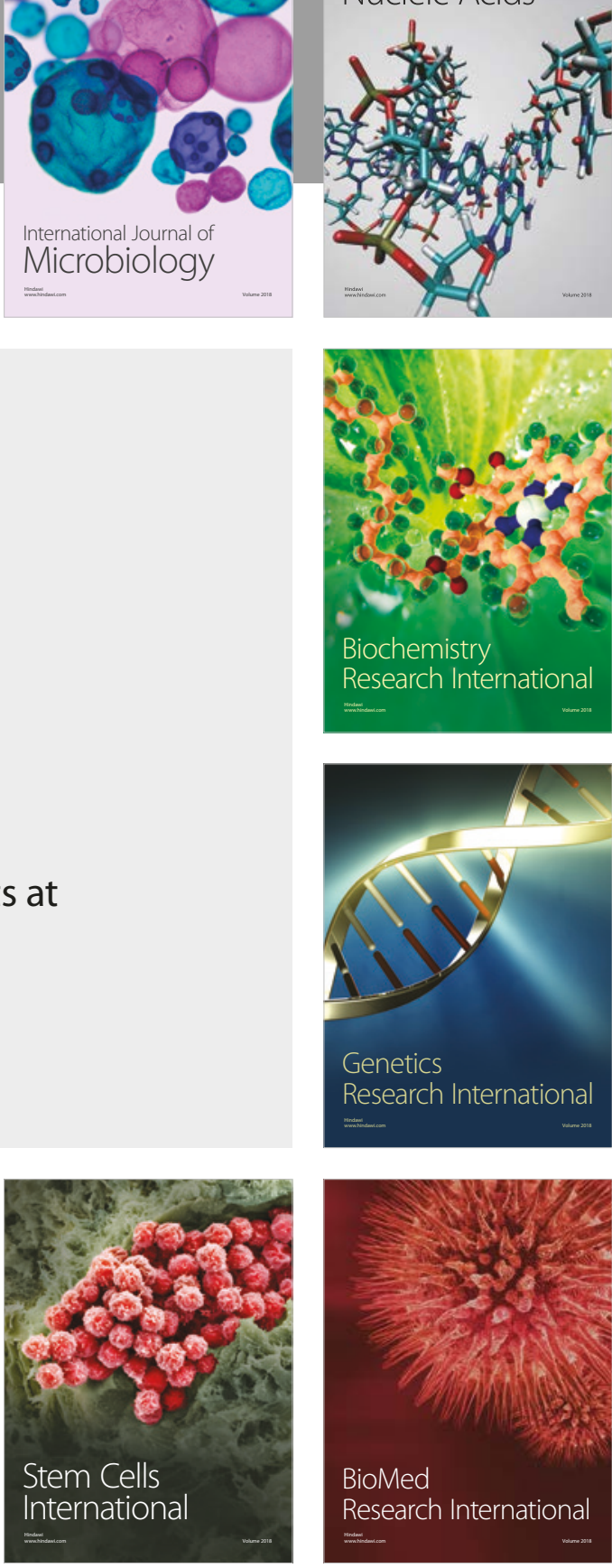
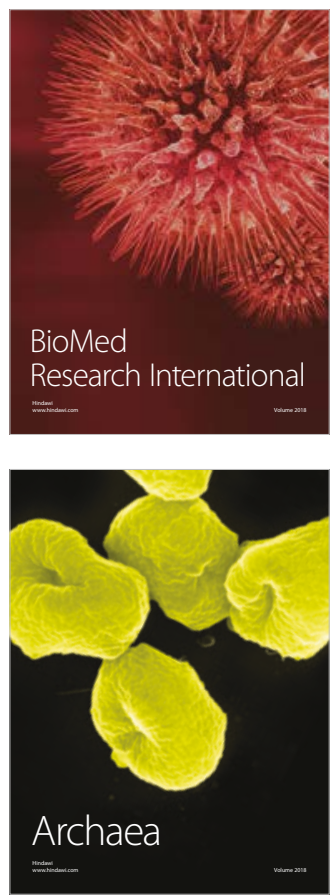